\title{
Original Research \\ Assessing the Abundance of Airborne Fungi in a Dairy Cattle Barn
}

\author{
Wojciech Pusz ${ }^{1 *}$, Elżbieta Pląskowska ${ }^{1}$, Ryszard Weber ${ }^{2}$, Wlodzimierz Kita ${ }^{1}$ \\ 'Department of Plant Protection, Wrocław University of Environmental and Life Sciences, \\ Grunwaldzki Sq. 24a, 50-363 Wrocław, Poland \\ ${ }^{2}$ Institute of Soil Science and Plant Cultivation - National Research Institute, Wrocław, \\ Orzechowa 61, 50-540 Wrocław, Poland
}

Received: 3 July 2014

Accepted: 3 August 2014

\begin{abstract}
The presented research aimed at determining the species composition and concentration of colony forming units (CFU) in two types of cattle barns for dairy cows and in a calf barn. The study was carried out in winter and summer 2012. The measurements took place in a free stall and tie stall barn and, additionally, in a calf barn. The mycological analysis of the air was conducted using the impact method, with an Air Ideal 3P apparatus. Spores of 45 species of fungi were found in cattle barn air, among them 36 species were collected in winter and 30 in summer. The fungal population was characterized by considerable variation across the seasons of the year and between bar types. The species most abundant irresepective of the season was Cladosporium herbarum. Winter conditions favored Penicillium nigricans, whereas summer was conducive to the development of Rhodotorula glutinis. The concentrations of fungal spores determined in the study were not a direct hazard to barn workers or animals.
\end{abstract}

Keywords: airborne fungi, mycobiota, bioaerosol, mycotoxins, cattle barns, animal hygiene

\section{Introduction}

Workers employed in animal farms are exposed to a number of factors negatively affecting their health [1-3]. One of the most serious problems in this context is the high frequency of disorders of the upper respiratory routes, mainly allergies and asthma $[4,5]$. These disorders are most probably related to exposure to airborne fungal spores as well as to those present in substrate, including barn bedding. It has been estimated that approximately 80 fungal taxa can be made responsible for allergic conditions in humans [6]. Many species of fungi-producing airborne spores can also produce detrimental mycotoxins, i.e. aflatoxins, ochratoxins, and trichotecenes [3, 7-9]. The high concentration of these airborne spores is usually associated

*e-mail: wojciech.pusz@up.wroc.pl with particular working environments and tasks, like uploading of grain or hay [10-13]. While the agricultural produce is being stored, the so-called "storage fungi" may develop and it happens most often at those instances when the stored material is not adequately dried prior to storing, or the storage conditions (e.g. air humidity) are irrelevant. The taxa that are most importantly included in the storage pathogen category are those belonging to the genera of Aspergillus and Penicillium [14]. They occur commonly in animal husbandry rooms, where they are specifically found in animal feed and in barn bedding $[2,3,15,16]$, but they are also present in miscellaneous kinds of human living space [17] as well as in public-use environments such as lecturing halls [18], banks, pharmacy shops [19], and even in health care institutions [20].

Species of Aspergillus and Penicillium genera are capable of producing mycotoxins, products of the secondary 
metabolism of the mycelial fungi. These are compounds of low molecular mass characterized by low polarity and high thermostability, which makes them resist decomposition in the pasteurization process or even in higher temperatures. Interestingly, they become degraded at basic environments and once they are exposed to UV radiation. In structural terms they are classified as aromatic or - less frequently as aliphatic hydrocarbons [21]. While entering the human body through the alimenary tract, respiratory route, or through dermal contact, mycotoxins exert their detrimental effect on the health of exposed humans [22]. Aspergillus spp. produce the following mycotoxins: aflatoxin B1, G1, and M1, ochratoxin A, and sterigamtocystine. The taxa od Penicillium spp. produce ochratoxine A, cytrynine, pauline, penitrem A. Moreover, Aspergillus spp. and Penicillium spp. are able to produce large numbers of conidia, which can also negatively affect the health status of humans and animals because these spores may themselves contain mycotoxins and as such are the most allergenic fungal organs [23]. The fungal genera in question can cause severe immunological disorders as well as infections of internal and external organs. Aspergillus spp. may induce invasive aspergiloses, otomycoses, onychomycoses, and allergic inflammatory conditions of the pulmonary alveoli, as well as other allergic reactions. They can be a factor of lung infections in patients showing immune deficiencies. These fungi are known to be the cause of sinusitis, dermatitis, and nail and cornea infections. They may as well induce deep infections of internal organs such as kidneys, endocardium, or the auditory canal. Exposure to species of Aspergillus genus may also result in hepatitis or arthritis. On the other hand, the taxa counted into Penicillium genus are mostly responsible for infections of skin, bone marrow, and intestines, but they are also known to infect kidneys and cornea, and cause fungal pneumonia, endocarditis peritonitis, and urinary tract infections and allergies [24].

The presented research was aimed at determining the species composition and the CFU concentration in two types of cattle barns for dairy cows and in a calf barn, in two seasons of the year.

\section{Experimental Procedures}

The study was carried out in two distinct terms: every week in January and in July of 2012. The airborne fungal spores were sampled in two types of barns: a free stall barn (203 animals) and a tie stall one (126 animals), and additionally in a calf barn (107 calves), all the property of the Cattle Breeding Center in Kamieniec Ząbkowicki (Lower Silesia). Sampling always took place between 9 and 10 a.m. Analysis employed the impact method using an Air Ideal 3P apparatus and PDA (potato dextrose agar) culturing medium (Biocorp). The volumes of the samples were $50 \mathrm{~L}, 100 \mathrm{~L}$, and $150 \mathrm{~L}$. In any one of the buildings the measurments were taken in 3 replicates, at 3 different spots of the barn: at the entrance, in the interior, and near the exit. The sampling device was positioned $1.5 \mathrm{~m}$ above the floor level of the barn. The sampled fungi were cultured for 7 days at $22^{\circ} \mathrm{C}$.
After incubation the appearing colonies were counted and fungi were identified taxonomically based on their morphology, using available monographic keys $[25,26]$. Then the number of CFU per $1000 \mathrm{~L}\left(1 \mathrm{~m}^{3}\right)$ of the air was calculated based on the number of the colonies grown on a Petri dish, according to the formula:

$$
X=(a \times 1000) / V
$$

...where: $a$ stands for the total number of fungal colonies that had grown on a Petri dish exposed to a sample of the air and $V$ is the volume of the air taken by the sampler $(\mathrm{L})$.

Out of all the sampled material, 16 species that occurred most frequently were selected for statistical analysis: Alternaria alternata, A. brasiliensis, Aspergillus flavus, Botrytis cinerea, Cladosporium cladosporioides, $C$. herbarum, Epicoccum nigrum, Fusarium oxysporum, Giberella avenacea, Penicillium notatum, P. lanosocoeruleum, $P$. nigricans, $P$. purpurogenum, P. velutinum, Rhodotorula rubra, and $R$. glutinis. Relations between the number of fungal species, the season, and barn type were assessed using log-linear analysis. Significant deviations from the expected values of the incidence of particular species calculated according to formula (1), point at an interaction between the variables. After the logarhitmic transformation of the expected values the model assumes linear form, which may be described in the following formula:

$$
\operatorname{Ln}\left(E_{i j}\right)=M+\lambda_{i}^{X}+\lambda_{j}^{Y}+\lambda_{i j}^{X Y}
$$

...where $E_{i j}$ - expected values, $M$ - general mean, $\lambda_{i}^{X}-$ the effect of ith value of variable $X, \lambda_{j}^{Y}$ - the effect of $\mathrm{j}$ th value of the variable $Y, \lambda_{i j}^{X Y}$ - the effect of interactions of $i t h$ value of the variable $X$, and $\mathrm{j} t h$ value of the variable $Y$.

The log-linear model allows for verification of hypothesis assuming no interactions between two or more experimental factors. It also enables assessment of effects of particular factors on the variability of the investigated population of fungi. In the next part of the study the structure and variability of the fungal population, as depending on the season of the year and barn type, was analyzed using correspondence analysis.

\section{Results}

The microclimatic conditions during the air sampling process were similar in the free stall and tie stall barn (Table 1).

In total, spores of 43 species of fungi were found in the air, 36 of them being sampled in winter and 30 in summer (Table 2). In the free stall barn the winter sampling resulted in collection of spores representing 25 species, whereas from the summer sampling spores belonging to 19 species were recorded. In the tie stall barn these numbers were 23 species in winter and 22 in summer. In the calf barn these numbers amounted to 26 and 23 , respectively.

The log-linear analysis has demonstrated that in high temperatures and in the high relative humidity prevailing in summer the number of the investigated taxa was higher 
Table 1. Microclimate conditions in the dairy houses.

\begin{tabular}{|l|c|c|c|c|}
\hline \multirow{2}{*}{$\begin{array}{c}\text { Location of } \\
\text { measurement }\end{array}$} & Temperature $\left[{ }^{\circ} \mathrm{C}\right]$ & Relative air humidity $[\%]$ & Temperature $\left[{ }^{\circ} \mathrm{C}\right]$ & Relative air humidity [\%] \\
\cline { 2 - 5 } & 18.0 & 78.2 & 21.0 & 67.2 \\
\hline Free stall & 17.0 & 71.9 & 22.0 & 65.0 \\
\hline Tie stall barn & 19.5 & 88.9 & 22.0 & 72.0 \\
\hline Calf barn & & & \\
\hline
\end{tabular}

compared to the winter results (Table 3). Moreover, in the free stall barn lower spore concentration was found compared to the tie stall type or to calf barn, and that was true irrespective of the season. Significant interaction between barn type and season points to the variable density of the investigated fungal population depending on the prevailing atmospheric conditions. In winter, considerably higher spore density was found in the tie stall barn compared to the other objects (Tables 4, 5). Conversely, in summer higher CFU density was observed in the calf barn.

Significant interaction between the species to fungi and the seasons of the year testifies to the differential effect of the fluctuating atmospheric conditions on the incidence of particular taxa. Out of the whole investigated population, Cladosporium herbarum shows higher CFU density irrespective of the seasons. On the other hand, winter conditions apparently favoured Penicillium nigricans, whereas the highest air concentration of Rhodotorula glutinis CFU was observed in the summer season.
Using correspondence analysis (CA), our study further determined the structure of relations between spore density of particular fungi and factors such as season of the year and barn type. Eigenvalues shown in the graph axes reflect the variance of the distribution of datapoints (i.e. of fungi species) for the first and second dimensions. The term inertia, as used within the CA, is a measure of datapoints distribution - variance of the original, 6-dimensional space. Based on Fig. 1, one may distinguish four groups of fungi according to their response to the barn type and the season of the year. The first group would include Aspergillus flavus, P. nigricans, and R. rubra, seen in the first part of the graph (Fig. 1). The second group is made of $R$. glutinis, $P$. velutinum, $B$. cinerea, and $A$. alternata. The third association is apparently distant from the previous two, and it contains only two species: P. purpurogenium and P. lanosocoeruleum. The fourth group, except for $F$. oxysporum, is located near the beginning of the coordinate system of the graph.

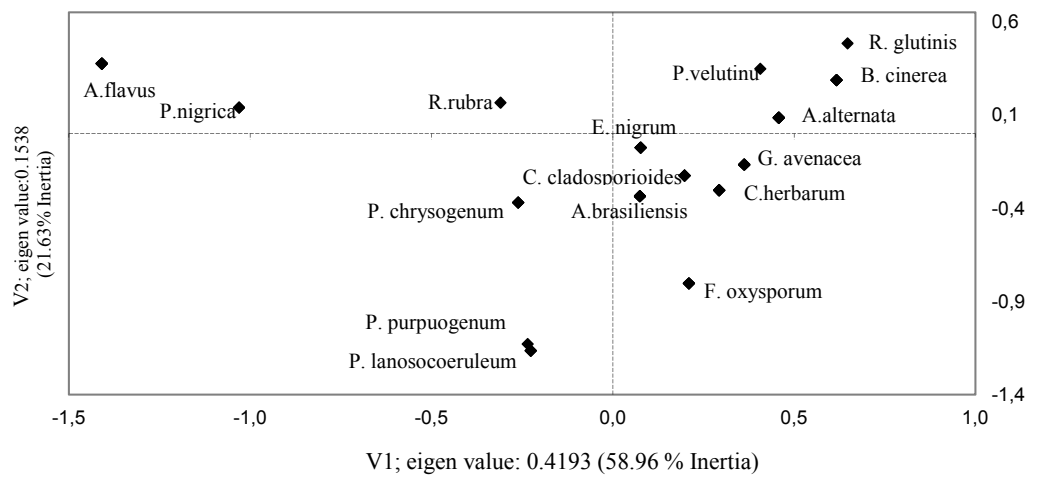

Fig. 1. Correspondence analysis of variability of individual species of fungi, depending on the type of barn and season.

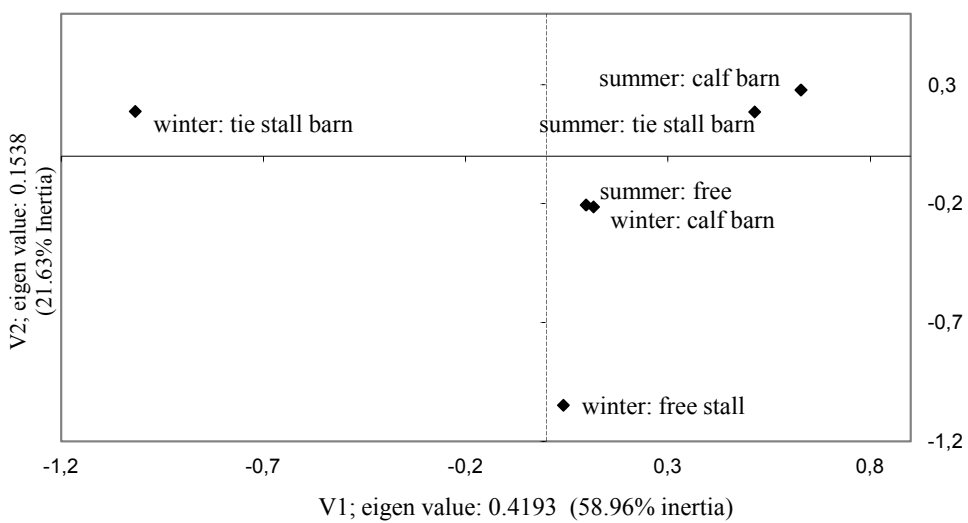

Fig. 2. Correspondence analysis of variability of the test population of fungi in individual barns, depending on the season. 
Table 2. The average value of fungal CFU $/ \mathrm{m}^{3}$ in the dairy houses.

\begin{tabular}{|c|c|c|c|c|c|c|}
\hline \multirow{2}{*}{ Fungal species } & \multicolumn{3}{|c|}{ Winter } & \multicolumn{3}{|c|}{ Summer } \\
\hline & Free stall & Tie stall barn & Calf barn & Free stall & Tie stall barn & Calf barn \\
\hline Absidia glauca Hagem & 20 & & & & 60 & \\
\hline Alternaria alternata (Fr.) Keissl. & 400 & 420 & 660 & 420 & 480 & 2260 \\
\hline Apiospora montagnei Sacc. & & 20 & & & & \\
\hline Aspergillus brasiliensis Varga, Frisvad \& Samson & 20 & 40 & 220 & & 40 & 20 \\
\hline Aspergillus candidus Link & & & & 40 & 40 & \\
\hline Aspergillus flavus Link & 2960 & 40 & 190 & 20 & 20 & 20 \\
\hline Aspergillus fumigatus Fresen. & 100 & & 20 & & & \\
\hline \multicolumn{7}{|l|}{ Aspergillis foetidus Thom \& Raper } \\
\hline Aspergillus versicolor (Vuill) Tirab. & & & 10 & & 160 & 160 \\
\hline Botrytis cinerea Pers. & & 40 & 200 & 200 & 300 & 620 \\
\hline Cladosporium cladosporioides (Fresen.) G.A. de Vries & 420 & 400 & 260 & 400 & 520 & 620 \\
\hline Cladosporium herbarum (Pers.) Link & 1280 & 740 & 1280 & 1140 & 1380 & 1900 \\
\hline Cylindrocarpon radicicola Wollenw. & & & & & & 20 \\
\hline Epicoccum nigrum Link & 100 & 340 & 260 & 460 & 320 & 300 \\
\hline Exerophilum sp. & & & 10 & & & 60 \\
\hline Fusarium oxysporum Schlecht. & 40 & & 130 & 60 & & 20 \\
\hline Gibberella avenacea R.J. Cook & 20 & 20 & 220 & & 20 & 120 \\
\hline Gibberella intricans Wollenw. & & 20 & 20 & 20 & 20 & \\
\hline Mucor hiemalis Wehmer & 20 & & & & 200 & \\
\hline Penicillium vulpinum (Cooke \& Massee) Seifert \& Samson & 20 & & & & & \\
\hline Penicillium frequentans Westling & & & 60 & & & 20 \\
\hline Penicillium implicatum Biourge & & 20 & 20 & & & 20 \\
\hline Penicillium janthinellum Biourge & 20 & & 20 & & & \\
\hline Penicillium lanoso-coeruleum Thom & 80 & 40 & 40 & 40 & & \\
\hline Penicillium nigricans K.M. Zalessky & 160 & 3240 & 440 & 580 & 120 & 40 \\
\hline Penicillium notatum Westling & 560 & 820 & 220 & 80 & 280 & 380 \\
\hline Penicillium purpurogenum Flerov & 800 & 440 & 40 & 160 & 100 & 140 \\
\hline Penicillium urticae Bainier & 60 & 20 & & 100 & & \\
\hline Penicillium velutinum J.F.H. Beyma & & 140 & 200 & 60 & 60 & 560 \\
\hline Penicillium waksmanii K.M. Zalessky & & 120 & 40 & & 100 & 20 \\
\hline Penicillium vermiculatum P.A. Dang. & & & & & 20 & 20 \\
\hline Penicillium aurantiogriseum Dierckx & 20 & & & & & \\
\hline Penicillium sp. & & & & 80 & 60 & 20 \\
\hline \multicolumn{7}{|l|}{ Phoma leveillei Boerema\& G.J. Bollen } \\
\hline Rhodotorula rubra (Schimon) F.C. Harrison & 20 & 620 & 200 & 280 & 260 & 200 \\
\hline Rhodotorula glutinis (Fresen.) F.C. Harrison & 40 & 480 & 220 & 380 & 2080 & 3320 \\
\hline Sarocladium strictum (W. Gams) Summerb. & 40 & 140 & 80 & & & \\
\hline Talaromyces funiculosus (Thom) Samson, Yilmaz, Frisvad \& Seifert & & & 20 & & & \\
\hline Talaromyces rugulosus (Thom) Samson, Yilmaz, Frisvad \& Seifert & 40 & 20 & & & & \\
\hline Talaromyces variabilis (Sopp) Samson, Yilmaz, Frisvad \& Seifert & 20 & & & & & \\
\hline Trichoderma harzianum Rifai & 20 & & & & & \\
\hline Truncatella hartigii (Tubeuf) Steyaert & 20 & & & & & \\
\hline Verticillium lecanii (Zimm.) Viégas & & & & 60 & & \\
\hline Total & 7300 & 8180 & 5080 & 4580 & 6640 & 10860 \\
\hline
\end{tabular}


Table 3. Tests of main effects, marginal and partial associations, and interactions between experimental factors.

\begin{tabular}{|c|c|c|c|c|c|c|}
\hline \multicolumn{2}{|c|}{ Effect } & $\begin{array}{l}\text { Degrees } \\
\text { of freedom }\end{array}$ & $\begin{array}{l}\mathrm{Chi}^{2} \text { partial } \\
\text { association }\end{array}$ & $\begin{array}{c}\text { Significant level } \\
\text { (p) }\end{array}$ & $\begin{array}{l}\mathrm{Chi}^{2} \text { marginal } \\
\text { association }\end{array}$ & $\begin{array}{c}\text { Significant level } \\
\text { (p) }\end{array}$ \\
\hline Fungal species & (1) & 15 & $9,839.47$ & $<0.001$ & 9839.47 & $<0.001$ \\
\hline Period of year & (2) & 1 & 15.13 & $<0.001$ & 15.13 & $<0.001$ \\
\hline Type of barn & (3) & 2 & $1,077.58$ & $<0.001$ & 1077.58 & $<0.001$ \\
\hline $1 \times 2$ & & 15 & $3,500.73$ & $<0.001$ & 4420.84 & $<0.001$ \\
\hline $1 \times 3$ & & 30 & $33,355.49$ & $<0.001$ & 4275.60 & $<0.001$ \\
\hline $2 \times 3$ & & 2 & 238.88 & $<0.001$ & 1158.99 & $<0.001$ \\
\hline
\end{tabular}

Fig. 2 reflects variation in fungal spore density between the different barn types, in winter or summer. Comparing species distribution as seen in Fig. 1 to the distribiution, in Fig. 2, of the points that represent barn types, one may observe some connections between them. In the free stall barn conditions in winter season the highest density of the spores of $P$. purpurogenum and $P$. lanosocoeruleum has been demonstrated. On the contrary, conditions prevailing in winter inside the tie stall barn were most conducive to the development of $A$. flavus, $P$. nigricans, and $R$. rubra. Furthermore, R. glutinis, P. velutinum, B. cinerrea, and

Table 4. Abundance of species of fungi in the winter, depending on the type of barn.

\begin{tabular}{|c|c|c|c|c|}
\hline \multirow[b]{2}{*}{ Species } & \multicolumn{3}{|c|}{ Type of barn } & \multirow[b]{2}{*}{ Total } \\
\hline & 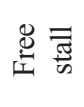 & 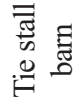 & 坖 & \\
\hline A. alternata & 133 & 140 & 220 & 493 \\
\hline A. brasiliensis & 6 & 14 & 73 & 93 \\
\hline A. flavus & 14 & 987 & 64 & 1065 \\
\hline B.cinerea & 0 & 14 & 67 & 81 \\
\hline C.cladosporioides & 140 & 134 & 87 & 361 \\
\hline C. herbarum & 427 & 247 & 427 & 1101 \\
\hline E. nigrum & 35 & 113 & 87 & 235 \\
\hline F. oxysporum & 14 & 0 & 44 & 58 \\
\hline G. avenacea & 6 & 6 & 74 & 86 \\
\hline P. notatum & 187 & 273 & 73 & 533 \\
\hline P. lanosocoeruleum & 27 & 14 & 14 & 55 \\
\hline P. nigricans & 54 & 1046 & 146 & 1246 \\
\hline P. purpurogenum & 267 & 146 & 14 & 427 \\
\hline P. velutinum & 0 & 47 & 67 & 114 \\
\hline R. rubra & 6 & 206 & 67 & 279 \\
\hline R. glutinis & 14 & 160 & 73 & 247 \\
\hline Total & 1330 & 3547 & 1597 & 6474 \\
\hline
\end{tabular}

A. alternata had been showing higher spore density inside the tie stall and calf barns in summer. Micrclimatic conditions of the winter in the calf barn and of the summer in free stall barn favored development of the other sampled species of fungi.

\section{Disscusion of the Results}

Fungi enter the animal husbandry space as airborne particles travelling through ventilation systems, but they are also transferred by humans. Conditions prevalent indoor,

Table 5. Abundance of species of fungi in the summer, depending on the type of barn.

\begin{tabular}{|c|c|c|c|c|}
\hline \multirow[b]{2}{*}{ Species } & \multicolumn{3}{|c|}{ Type of barn } & \multirow[b]{2}{*}{ Total } \\
\hline & 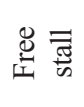 & 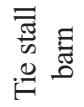 & 㫕 & \\
\hline A. alternata & 140 & 160 & 753 & 1053 \\
\hline A. brasiliensis & 0 & 14 & 6 & 20 \\
\hline A.flavus & 6 & 6 & 6 & 18 \\
\hline B.cinerrea & 67 & 100 & 207 & 374 \\
\hline C.cladosporioides & 134 & 173 & 207 & 514 \\
\hline C.herbarum & 380 & 460 & 634 & 1474 \\
\hline E.nigrum & 154 & 107 & 100 & 361 \\
\hline F.oxysporum & 20 & 0 & 6 & 26 \\
\hline G.avenacea & 0 & 6 & 40 & 46 \\
\hline P.chrysogenum & 27 & 93 & 126 & 246 \\
\hline P.lanosocoeruleum & 14 & 0 & 0 & 14 \\
\hline P.nigricans & 193 & 40 & 14 & 247 \\
\hline P.purpurogenum & 54 & 32 & 46 & 132 \\
\hline P.velutinum & 20 & 20 & 187 & 227 \\
\hline R.rubra & 93 & 87 & 67 & 247 \\
\hline R.glutinis & 127 & 693 & 1106 & 1926 \\
\hline Total & 1429 & 1991 & 3505 & 6925 \\
\hline
\end{tabular}


mostly high relative air humidity, may affect their development there. Nevertheless, some authors have found no variation in CFU value between the summer and winter seasons [23]. Our results do not conform to that notion. Conversely, they apparently indicate that, in the winter, higher CFU concentrations occur in tie stall barns, whereas in free stall and in calf barns these values are lower in winter compared to summer. Calf barn results from Denmark confirm such a conclusion [28]. In turn, during a study conducted in cattle barns in India [29], maximum concentrations of fungal spores were recorded during periods of humid weather, i.e. during the monsoon season. There, the taxa of the genus Aspergillus predominated, such as Penicillium, making up $>50 \%$ of all the collected spores, as well as those of Cladosporium, with their mean density fluctuating around $900 \mathrm{CFU}$. The CFU density oscillated around this 900 mean value between 350 and even as much as $2200 \mathrm{CFU}$. Inside the barns in India the CFU density was higher in winter season, when the prevailing outside temperatures were relatively low. The factors that most importantly promote the increase in CFU concentration are temperature and air relative humidity prevailing indoors [29]. In our study, the microclimatic conditions were similar at the time of air sampling from the free stall and tie stall barns.

Many authors report on CFU density in cattle barns being orders of magnitude higher than that found in our study. Blom et al. [28] have determined CFU concentrations in calf barns as $10^{3}-10^{5} \mathrm{CFU} / \mathrm{m}^{3}$. Authors from Finland show even higher concentrations, amounting to $10^{5}-10^{7} \mathrm{CFU} / \mathrm{m}^{3}$ [15]. The spore densities found in our study were as high as $1,693 \mathrm{CFU} / \mathrm{m}^{3}$ in winter and 3,614 $\mathrm{CFU} / \mathrm{m}^{3}$ during summer. Such a discrepancy may likely reflect some versatility in cattle barn design, including the design, working conditions, and the resulting efficacy of the ventilation systems used [29]. Barns in which the present study were carried out were renovated in the course of recent years, which have made their ventilation systems work efficiently.

During the winter season sampling the species of Aspergillus and Penicillium genera showed the highest percentage proportion in the sampled fungal material, whereas in the summer season the relative proportion altered. The species of Cladosporium genus and Alternaria alternata were isolated the most in summer sampling. These results conform to the findings of other authors [2, 3, 15, 16]. Fungi of Cladosporium sp. and the species of $A$. alternata are ubiquitous by the end of plant growth season within the canopies of cereals and rape, causing black rot in both the crops and disseminating their spores. This may likely contribute to their abundant incidence in the air of cattle barns. Ghasian and Maghsood [3] reported the presence of 17 species of these fungi in cattle barns. In our study 45 species of fungi were found in total. On the other hand, Adhikari et al. [2] found only 10 fungi species in dairy cattle barns.

The majority of the fungi found in the air in Finnish barns belong to the genera of Aspergillus and Penicillium, although Cladosporium sp. had been sampled as well. Taxa of Cladosporium sp. had been also isolated from the straw used as barn bedding. This may explain considerably higher concentrations of Cladosporium herbarum recorded in the calf barn, where the bedding is relatively often replaced with new material [15]. A similar situation is observed with genus Fusarium; concentrations of the spores of Fusarium sp. in calf barn are higher compared to free stall or tie stall barn air. The straw used as barn bedding should always be dry and show no symptoms of infestation by fungi [29].

The most numerous fraction of the fungi associations recorded from the air of either conventional or industrial barns in Iran was made up of Aspergillus sp. (>35\%) and Penicillium sp. (23\%). Fusarium, Cladosporium, and Alternaria had been found there as well. Of all the species of Aspergillus, A. flavus was the most abundant taxon, sampled from conventional barns, where straw was used as bedding. In the present study this same fungus was mostly determined in the air samples coming from the tie stall barn and calf barn, where large volumes of straw were used on the barn floor. This species creates a direct risk of pathological conditions of hands and mucous membranes in animal husbandry workers [16].

Interestingly, our results do not conform fully to those obtained by Ghasian and Magshood [3]. These authors have shown that in industrial barns the CFU concentration is twice as high compared to conventional ones, both in winter and summer. Our results demonstrate the opposite: in the tie stall barn, representing conditions close to conventional barn design, we have recorded CFU concentrations nearly two-fold higher than in the free stall barns, which more closely resemble industrial husbandry.

The presence in the atmosphere of a barn of the spores of Aspergillus and Penicillium sp. may represent a direct health threat for animal husbandry workers. For the sheer fact that they are capable of producing mycotoxins [30] or able to cause mycoses and other respiratory system diseases [31], these fungi are considered one of the important components of indoor bioaerosol. Nevertheless, in order to confirm such a causative relationship in any individual case it is necessary to conduct a series of molecular tests, as not all of the isolates derived from air sampling show the ability to synthesize mycotoxins [32, 33].

Last but not least, the spores of species belonging to the genus Rhodotorula had been found in the atmosphere of the investigated dairy and calf barns. The highest number of colonies of these taxa had been cultured from the air samples taken in the calf barn in summer. This finding remains in agreement with results of some other authors $[34,35]$. The fungi were isolated from air samples in such barns in which large amounts of hay had been both stored and used as floor bedding. There, the taxa of Rhodotorula spp. made up to $30 \%$ of all total number of collected fungal spores [34]. Fungi of Rhodotorula spp. directly compromise the health status of cattle of different age groups, as they cause mycoses of ear and other organs in animals [35]. 


\section{Conclusions}

1. The investigated atmospheric fungal association was characterized by considerable variability depending on the season of the year and barn type.

2. Within the association, the species of Cladosporium herbarum showed higher air concentration of its CFU, irrespective of the season.

3. Winter conditions favored development of Penicillium nigricans, whereas summer was conducive to Rhodotorula glutinis.

4. During winter the variability in CFU density of particular species of fungi was rather high. On the other hand, the spore counts of individual species in samples taken in summer differed less from one another.

5. In winter the variation in abundance of individual species is highly dependent on barn type. On the contrary, in the summer the associations sampled from different types of barns differed less in their species composition.

6. We consider it necessary that in order to prevent potential threats to life and health status of both husbandry workers and animals, regular monitoring of the aeromycological composition of bioaerosol in large dairy barns should be carried out.

\section{References}

1. MAY J J., KULLMAN G J. Agricultural safety and health in a new century. Am J Ind Med 2, 1, 2002.

2. ADHIKARI A., SEN M. M., GUPTA-BHATTACHARYA S., CHANDA S. Volumetric assessment of airborne fungi in two sections of a rural indoor dairy cattle shed. Environment International 29, 1071, 2004.

3. GHASIAN S. A., MAGSHOOD A. H. Occurrence of aflatoxigenic fungi in cow feeds during the summer and winter season in Hamadan, Iran. African Journal of Microbiology Research 5, (5), 516, 2011.

4. DELUCA A. J. Harmful fungi in both Agriculture and Medicine. Rev. Iberoam. Micol. 24, 3, 2007.

5. GILBERT Y., DUCHAINE C. Bioaerosols in industrial environments: a review. Canadian Journal of Civil Engineering 36, (12), 1873, 2009.

6. BROŻEK J. L., BOUSQUET J., BAENA-CAGNANI C. E., BONINI S., CANONICA G. W., CASALE T. B., SCHÜNEMANN H. J. Allergic Rhinitis and its Impact on Asthma (ARIA) guidelines: 2010 revision. Journal of Allergy and Clinical Immunology 126, (3), 466, 2010.

7. OLIVEIRA M., RIBEIRO H., DELGADO J. L., ABREU I. The effects of meteorological factors on airborne fungal spore concentration in two areas differing in urbanisation level. International journal of biometeorology 53, (1), 61, 2009.

8. FINK-GREMMELS. J. The role of mycotoxins in the health and performance of dairy cows. The Veterinary Journal 176, (1), 84, 2008.

9. PUSZ W., KITA W., DANCEWICZ A., WEBER R. Airborne fungal spores of subalpine zone of the Karkonosze and Izerskie Mountains (Poland). Journal of Mountain Sciences 10, (6), 940, 2013.

10. LAPPALAINEN S., NIKULIN M., BERG S., PARRIKA P., HINTIKKA E. L., PASANEN A L. Fusarium toxins and fungi associated with handling of grain on eight Finnish farms. Atmos Environ 17, 3059, 1996.

11. BOXALL A., HARDY A., BEULKE S., BOUCARD T., BURGIN L., FALLOON P D., WILLIAMS R. J. Impacts of climate change on indirect human exposure to pathogens and chemicals from agriculture. Environmental Health Perspectives, 117, (4), 508, 2008.

12. AIMANIANDA V., BAYRY J., BOZZA S., KNIEMEYER O., PERRUCCIO K., ELLURU S. R., LATGÉ J. P. Surface hydrophobin prevents immune recognition of airborne fungal spores. Nature 460, (7259), 1117, 2009.

13. JESTOI M. Emerging Fusarium-mycotoxins fusaproliferin, beauvericin, enniatins, and moniliformin, a review. Critical reviews in food science and nutrition, 48, (1), 21, 2008.

14. MAGAN N., ALDRED D., MYLONA K., LAMBERT R. J. Limiting mycotoxins in stored wheat. Food Additives and Contaminants 27, (5), 644, 2010.

15. HANHELA R., LOUHELAINEN K., PASANEN A. L. Prevalence of microfungi in Finnish cow barns and some aspects of the occurrence of Wallemia sebia and Fusaria. Scand J Work Environ Health 21, 223, 1995.

16. ABD-ELLAL A. M., MOHAMED M. M., AWDALLAH M. I. Potential airborne microbial hazards for workers on dairy and beef cattle farms in Egypt. Vet. Ital. 45, (2), 275, 2009.

17. OGÓREK R., PLĄSKOWSKA E., KALINOWSKA K., FORNALCZYK P., MISZTAL A., BUDZIAK J. The analysis of mycological air pollution in selected rooms of student hostels. Mikol. Lek., 18, (4), 201, 2011.

18. OGÓREK R., PLĄSKOWSKA E. The mycological analysis of air in selected public rooms. Preliminary study. Mikol. Lek., 18, (1), 24, 2011.

19. PLĄSKOWSKA E., KOROL M., OGÓREK R. Fungi found in air-conditioned room. Part I. Mikol. Lek., 18, (4), 178, 2011.

20. OGÓREK R., KALINOWSKA K., PLĄSKOWSKA E., BARAN E., MATKOWSKI K. Mycological air pollutions on different culture mediums in selected rooms of Dermatology Department. Part II. Mikol. Lek., 18, (2), 79, 2011.

21. PŁAWIŃSKA-CZARNAK J., ZARZYŃSKA J. Mycotoxins in food products of animal origin. Mikol. Lek., 17, (2), 128, 2010.

22. OMURTAG G Z. Fumonisins, trichothecenes and zearalenone in cereals. International Journal of Molecular Sciences 9, (11), 2062, 2008.

23. DUARTE S. C., LINO C. M., PENA A. Ochratoxin A in feed of food-producing animals: An undesirable mycotoxin with health and performance effects. Veterinary microbiology 154, 1, 2011.

24. PUSZ W., OGÓREK R. The potential dangerous of fungi associated with tobacco material during storage on warehouse workers. Mikologia Lekarska, 19, (1), 37, 2012.

25. PITT J. I., HOCKING A. D. Fungi and food spoilage. New York, Springer, 2009.

26. WATANABE T. Pictorial atlas of soil and seed fungi: morphologies of cultured fungi and key to species. CRC press, 2011.

27. EDUARD W. Fungal spores: a critical review of the toxicological and epidemiological evidence as a basis for occupational exposure limit setting. Critical reviews in toxicology, 39, (10), 799, 2009.

28. BLOM J.Y., MADSEN E.B., KROGH H.V., WOLSTRUM J. Numbers of airborne bacteria and fungi in calf houses. Nord Vet. Med. 36, 215, 1984. 
29. ADHIKARI A, REPONEN T, LEE S, Assesment of human exposure to airborne fungi in agricultural confinements: personal inhalable sampling versus stationary sampling. Ann. Agric. Environ. Med. 11, 269, 2011.

30. CABRAL J. P. Can we use indoor fungi as bioindicators of indoor air quality? Historical perspectives and open questions. Sci. Total Environ. 408, 4285, 2012.

31. BAUR X. Airborne allergens and irritants in the workplace. Allergy and Allergic Diseases 1, 1017, 2009.

32. VISHWANATH V., SULYOK M., LABUDA R., BICKER W., KRSKA R. Simultaneous determination of 186 fungal and bacterial metabolites in indoor matrices by liquid chromatography/tandem mass spectrometry. Analytical and bioanalytical chemistry 395, (5), 1355, 2009.
33. REN P., AHEARN D. G., CROW S. A. Comparative study of Aspergillus mycotoxin production on enriched media and construction material. J. Ind. Microbiol. Biotechnol. 23, 209, 1999.

34. REBOUX G., REIMAN M., ROUSSEL S., TAATTOLA K., MILLON L., DALPHIN J., PIARROUX R. Impact of agricultural practices on microbiology of hay, silage and flour on finnish and french farms. Ann Agric Environ Med 13, 267, 2006.

35. DUARTE E.R., RESENDE J.C., ROSA C.A., HAMDAN J.S. Prevalence of yeasts and mycelial fungi in bovine parasitic otitis in the State of Minas Gerais, Brazil. J. Vet. Med. 48, 631, 2001. 